\title{
Gotbic Renaissance
}

A reassessment

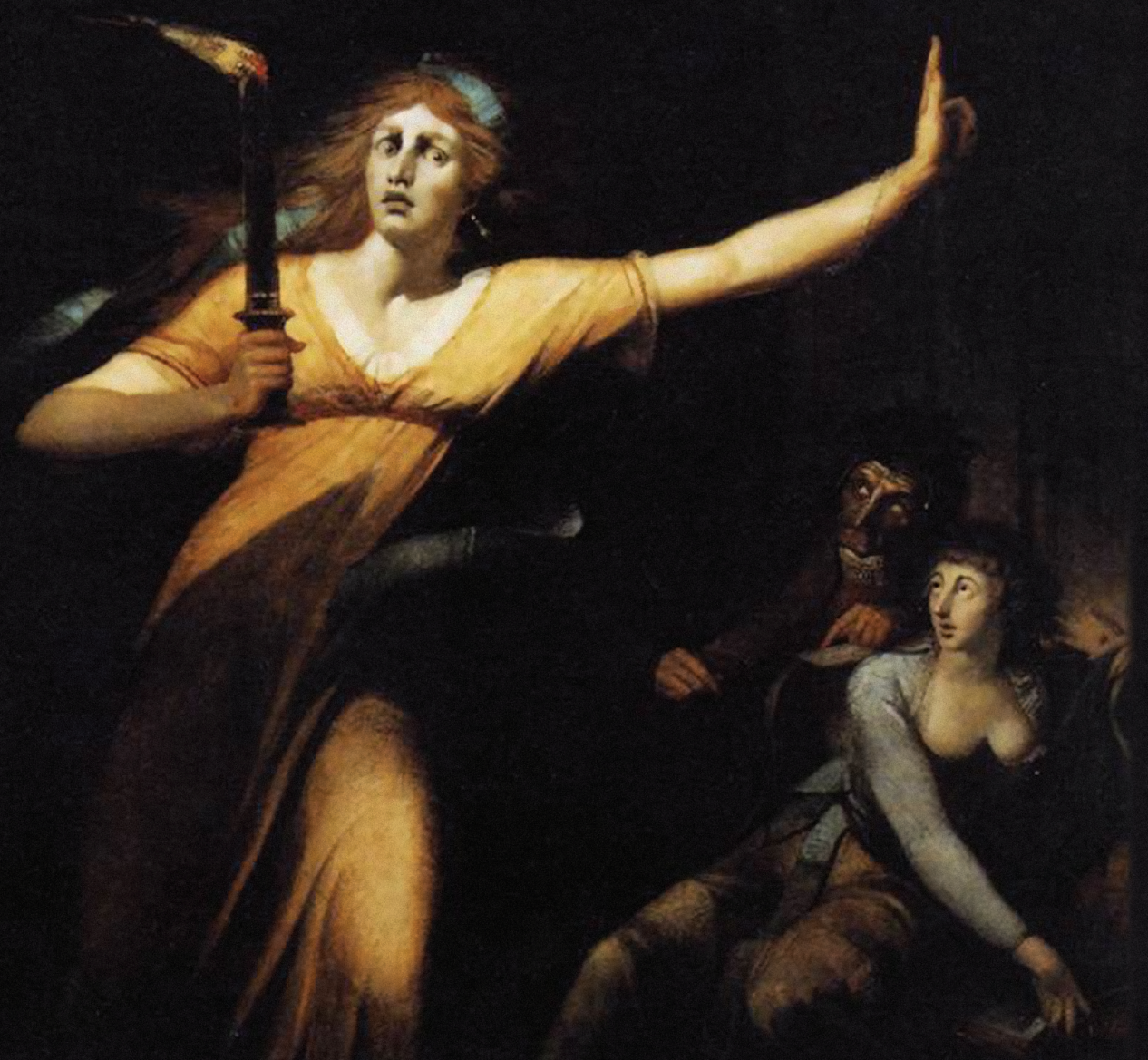

Edited by

Elisabeth Bronfen \& Beate Neumeier 


\section{Gothic Renaissance}

\section{MANCHESTER 1824}

Manchester University Press 
Elisabeth Bronfen and Beate Neumeier - 9781526111159 Downloaded from manchesterhive.com at 04/26/2023 01:29:04PM 


\title{
Gothic Renaissance
}

\author{
A reassessment
}

\author{
Edited by \\ ELISABETH BRONFEN \\ and BEATE NEUMEIER
}

Manchester University Press

Manchester and New York

distributed exclusively in the USA by Palgrave Macmillan 
Copyright (C) Manchester University Press 2014

While copyright in the volume as a whole is vested in Manchester University Press, copyright in individual chapters belongs to their respective authors, and no chapter may be reproduced wholly or in part without the express permission in writing of both author and publisher.

Published by Manchester University Press

Oxford Road, Manchester M13 9NR, UK

and Room 400, 175 Fifth Avenue, New York, NY 10010, USA

www.manchesteruniversitypress.co.uk

Distributed exclusively in the USA by

Palgrave Macmillan, 175 Fifth Avenue, New York,

NY 10010, USA

Distributed exclusively in Canada by

UBC Press, University of British Columbia, 2029 West Mall, Vancouver, BC, Canada V6T 1Z2

British Library Cataloguing-in-Publication Data

A catalogue record for this book is available from the British Library

Library of Congress Cataloging-in-Publication Data applied for

ISBN 9780719088636 hardback

First published 2014

The publisher has no responsibility for the persistence or accuracy of URLs for external or any third-party internet websites referred to in this book, and does not guarantee that any content on such websites is, or will remain, accurate or appropriate.

Typeset in Sabon by

Koinonia, Manchester 